\title{
Late Holocene vegetation, fire, climate and upper forest line dynamics in the Podocarpus National Park, southeastern Ecuador
}

\author{
Fernando Rodríguez $\cdot$ Hermann Behling
}

Received: 12 October 2009/Accepted: 16 March 2010/Published online: 19 May 2010

(C) The Author(s) 2010. This article is published with open access at Springerlink.com

\begin{abstract}
Late Holocene vegetation, fire, climate and upper forest line dynamics were studied based on detailed pollen and charcoal analyses. Two sediment cores, from the Rabadilla de Vaca mire (RVM) and the Valle Pequeño bog (VP), with an age of about 2100 and $1630 \mathrm{cal}$ yrs B.P., respectively, were taken at the modern upper forest line in the Parque Nacional Podocarpus (Podocarpus National Park) in southeastern Ecuador. The two pollen records reflect relatively stable vegetation with slight changes in floral composition during the recorded period. Changes of the proportion between subpáramo and páramo vegetation are related to lower and higher frequency of fires. The RVM records show that the upper forest line moved to a higher elevation between 1630 and $880 \mathrm{cal}$ yrs B.P., stabilising after $310 \mathrm{cal} \mathrm{yrs} \mathrm{B.P.} \mathrm{Human} \mathrm{impact} \mathrm{is} \mathrm{suggested} \mathrm{by}$ a high fire frequency, mainly between $1800-1600$ and 880 $310 \mathrm{cal}$ yrs B.P. The VP records indicate no marked changes in the upper forest line. The charcoal records suggest an increased human impact from $230 \mathrm{cal}$ yrs B.P. to the present. The results indicate that high fire frequency is an important factor in reducing the expansion of subpáramo vegetation and upper montane rainforest and in favouring the distribution of grass páramo. Since there is a clear correlation between fire and vegetation dynamics, it is difficult to detect how far climate change also played a significant role in upper forest line changes during the late Holocene.
\end{abstract}

Communicated by E.C. Grimm.

F. Rodríguez $(\bowtie) \cdot H$. Behling

Department of Palynology and Climate Dynamics, Albrechtvon-Haller Institute for Plant Sciences, University of Göttingen, Untere Karspüle 2, 37073 Göttingen, Germany

e-mail: Fernando.Rodriguez@biologie.uni-goettingen.de
Keywords Ecuador - Upper forest line - Fire history · Climate change $\cdot$ Palynology $\cdot$ Late Holocene

\section{Introduction}

The current altitudinal position of the Andean upper forest line (UFL) indicated by the uppermost forest patches is, to a large extent, the result of past ecological processes influenced by environmental changes including climate, fire and land use. These forest patches are interpreted as remnants of high altitude forests now destroyed by anthropogenic fires and forest clearance (Ellenberg 1958; Laegaard 1992; Sarmiento and Frolich 2002). Reconstruction of vegetation history is therefore an essential tool for understanding the dynamics of the UFL positions. The limit between montane rainforest and páramo grassland has important ecological and socioeconomic relevance. Studies on deforestation in Ecuador have estimated that only $4 \%$ of the forests on the western Andean slope are left. In the central valley, almost no natural forests are left because of the long occupation history and, in particular, increasing human impact during recent decades (Dodson and Gentry 1991). The potential position of the UFL is still not known due to a lack of both ecological and historical information about tropical ecosystems. According to some authors, the uppermost forest patches found above the actual tree line indicate the potential UFL. However, there is no evidence that these highest forest patches have ever been connected (Islebe and Hooghiemstra 1997; Wille et al. 2002), and present patches are mostly restricted to special micro-sites such as ravines and boulder slopes (Troll 1959; Walter and Medina 1969). The situation of forest patches at lower altitudes, close to the actual UFL, is not well known. These may also rely on unique local conditions or they may be 
remnants of formerly more extensive forest (Miehe and Miehe 1994; Kessler 2002; Bakker et al. 2008).

A few palaeoenvironmental records are available from southern Ecuador and neighbouring countries (Fig. 1). Studies from southwestern Ecuador in the Cajas National Park on the Western Cordillera at 3,700 m indicate that there was a herb páramo there in the Late-glacial period (17000-11000 cal yrs B.P.), reflecting climatic conditions colder and moister than those of today (Hansen et al. 2003). During the Holocene, Polylepis became more frequent and reached its maximum during the mid Holocene period. The climate was warmer with a more moderate seasonality during the early Holocene than it is nowadays. Fires were much more frequent during the early and mid Holocene than during the Late-glacial period. However, after $4000 \mathrm{cal}$ yrs B.P., the vegetation changed and the decrease of charcoal particles suggests a change towards moister conditions (Hansen et al. 2003). The results of the 17000 yrs B.P. old record of the Paso El Tiro, which is today covered by subpáramo vegetation, provide important insights on past vegetation, climate and fire history (Niemann and Behling 2008a).

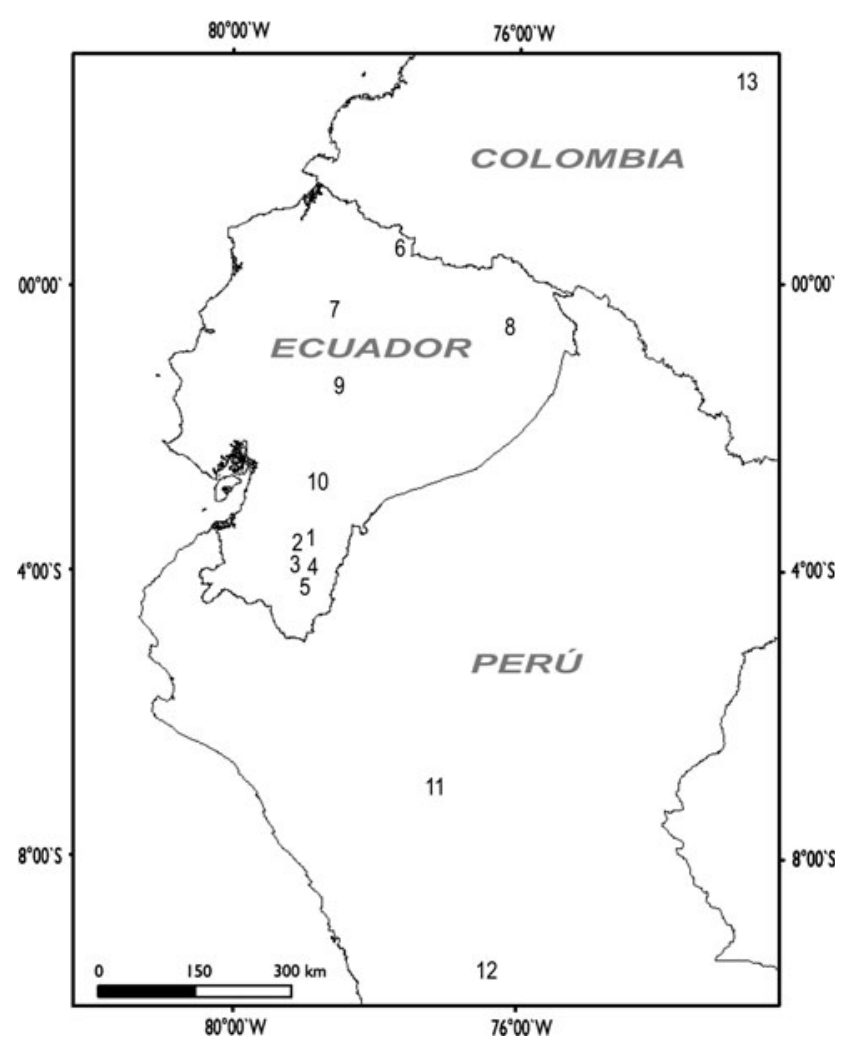

Fig. 1 Map of South America showing the study sites mentioned in the text. 1, Laguna Zurita; 2, Paso El Tiro; 3, Cocha Caranga; 4, Laguna Rabadilla de Vaca; 5, Cerro Toledo; 6, Guandera; 7, Pantano de Pecho; 8, Río Napo; 9, Laguna Yambo; 10, Lago Surucucho; 11, Laguna Chochos; 12, Huascarán; 13, Laguna Loma Linda
The Holocene history of UFL dynamics in the northern Andes has been addressed by an increasing number of palynological studies since the 1960s (van der Hammen and González 1960; van Geel and van der Hammen 1973; Hooghiemstra 1984; Colinvaux 1997; Hansen et al. 2003). However, there is no consensus about what happened there during the Holocene, as different pollen studies and their interpretations are often contradictory, and the timing of events is somewhat uncertain (Markgraf 1989; van 't Veer et al. 2000; Marchant et al. 2001).

Vélez et al. (2003) studied areas situated between the western and central Andean Cordilleras in Colombia, showing the dynamics of forest expansion/reduction with a clear increase in wetness during the mid Holocene. On the eastern Andean Cordillera, pollen records also show dry and cold conditions during the Late Pleistocene, very wet conditions for the early to mid Holocene, and dry conditions during the mid to late Holocene, while on the eastern savannas, records suggest dry conditions during the early Holocene and generally wet conditions for the mid and late Holocene (Behling and Hooghiemstra 1998, 2000).

Predictions of future global change suggest that changes in biodiversity composition and distribution are likely to occur in these ecosystems (IPCC 2007). Higher temperatures together with human influence will allow fires to occur more frequently and will increasingly transform the landscape.

Two sediment cores were collected at the modern upper forest limit (UFL) and studied by pollen and charcoal analysis, in order to obtain long-term records of vegetation dynamics in the study area. Four main questions will be addressed: (1) What was the nature of vegetation, fire and climate dynamics in the Parque Nacional Podocarpus (Podocarpus National Park, PNP) during the late Holocene? (2) How dynamic or stable were the vegetation and UFL during the late Holocene in the upper region of the PNP? (3) Which environmental factors have driven possible changes in vegetation and UFL dynamics? (4) Has fire, natural or anthropogenic, played a role in the dynamics of the UFL during the late Holocene? See also Brunschön et al. (2010) who studied a reconstruction of local environmental conditions over the past 500 years with a high-resolution multiproxy approach using pollen, spore, charcoal and XRF analyses at Laguna Campana in the PNP.

\section{Study area}

\section{Location}

The Parque Nacional Podocarpus (PNP) region is located in the southeastern Ecuadorian Andes, and occupies $1,460 \mathrm{~km}^{2}$ between ca. $04^{\circ} 00^{\prime}$ to $04^{\circ} 30^{\prime} \mathrm{S}$ and $79^{\circ} 10^{\prime}$ to 
$78^{\circ} 45^{\prime} \mathrm{W}$ (Fig. 2). Two study sites were selected on the western slope of the eastern Cordillera (Cordillera Real) at the modern upper forest limit. The first, Rabadilla de Vaca mire $(\mathrm{RVM})$, is a $30 \times 20 \mathrm{~m}^{2}$ peat bog located on a slope at the transition from upper montane rainforest (UMF) to subpáramo vegetation, situated at $04^{\circ} 15^{\prime} 23,7^{\prime \prime} \mathrm{S}$, and $79^{\circ} 07^{\prime} 15,3^{\prime \prime} \mathrm{W}$ at $3,200 \mathrm{~m}$ a.s.l. about $10 \mathrm{~km}$ east of the small village of Vilcabamba at $1,700 \mathrm{~m}$. The second site is Valle Pequeño bog (VP), a small isolated valley $4 \times 20 \mathrm{~m}^{2}$ filled with organic-rich sediment deposits. The site is located $16.5 \mathrm{~km}$ north from the RVM site and about $12 \mathrm{~km}$ south of the town of Loja, at $04^{\circ} 06^{\prime} 57,9^{\prime \prime} \mathrm{S}$, and $79^{\circ} 10^{\prime} 19,4^{\prime \prime} \mathrm{W}$ at $3,244 \mathrm{~m}$ a.s.l. near the Cajanuma entrance close to the border of the PNP, also located within subpáramo vegetation.

Geomorphology and geology

The Andes of southern Ecuador and northern Peru encompass the so-called Andean depression (Depression de Girón-Cuenca in Ecuador and Huancabamba in Peru). The main peaks of the mountains in this depression reach about 4,000 $\mathrm{m}$ in the Nudo de Loja, from which the inter-Andean Sierras stretch towards the southwest, south and southeast, all interrupted and dissected by valleys and basins. Active volcanoes are absent (Richter and Moreira-Muñoz 2005). The southern Cordillera Real is mainly part of the Zamora series, consisting of Palaeozoic metamorphic rocks of widely varying metamorphic grades. Local bedrock is dominated by semipelites, quartzites and black phylites with some granitic intrusions (Litherland et al. 1994).

\section{Climate}

The climate in the southeastern Ecuadorian Andes Cordillera is influenced by warm moisture-laden air from the Amazon lowland, which collides with cold mountain air masses (Emck 2007). The study area is located between the humid Amazon basin and the dry inter-Andean valley. East of the Cordillera, precipitation and humidity rise continuously to the mountain crests accompanied by increasing wind speed. Inside the PNP, at 3,100 m, rainfall up to $6,000 \mathrm{~mm} \mathrm{a}^{-1}$ has been measured. In contrast, the inter-Andean basin receives generally less than $1,000 \mathrm{~mm} \mathrm{a}^{-1}$ (Emck 2007; Bendix et al. 2008). The main rainy season lasts from April to August, but rainfall is high throughout the year. As part of the so-called Andean depression, all summits in the southern Ecuadorian Andes are below the present-day snowline. The eastern Andean mountains form a division that separates the moist eastern slopes of the Andes from the dry inner Andean basins such as the Loja and Catamayo basins. Between the eastern slopes of the eastern Cordillera and the dry valley of Catamayo, which are only $70 \mathrm{~km}$ apart, the annual rainfall drops from over 4,000 to $300 \mathrm{~mm}$ (Bendix and Rollenbeck 2004).

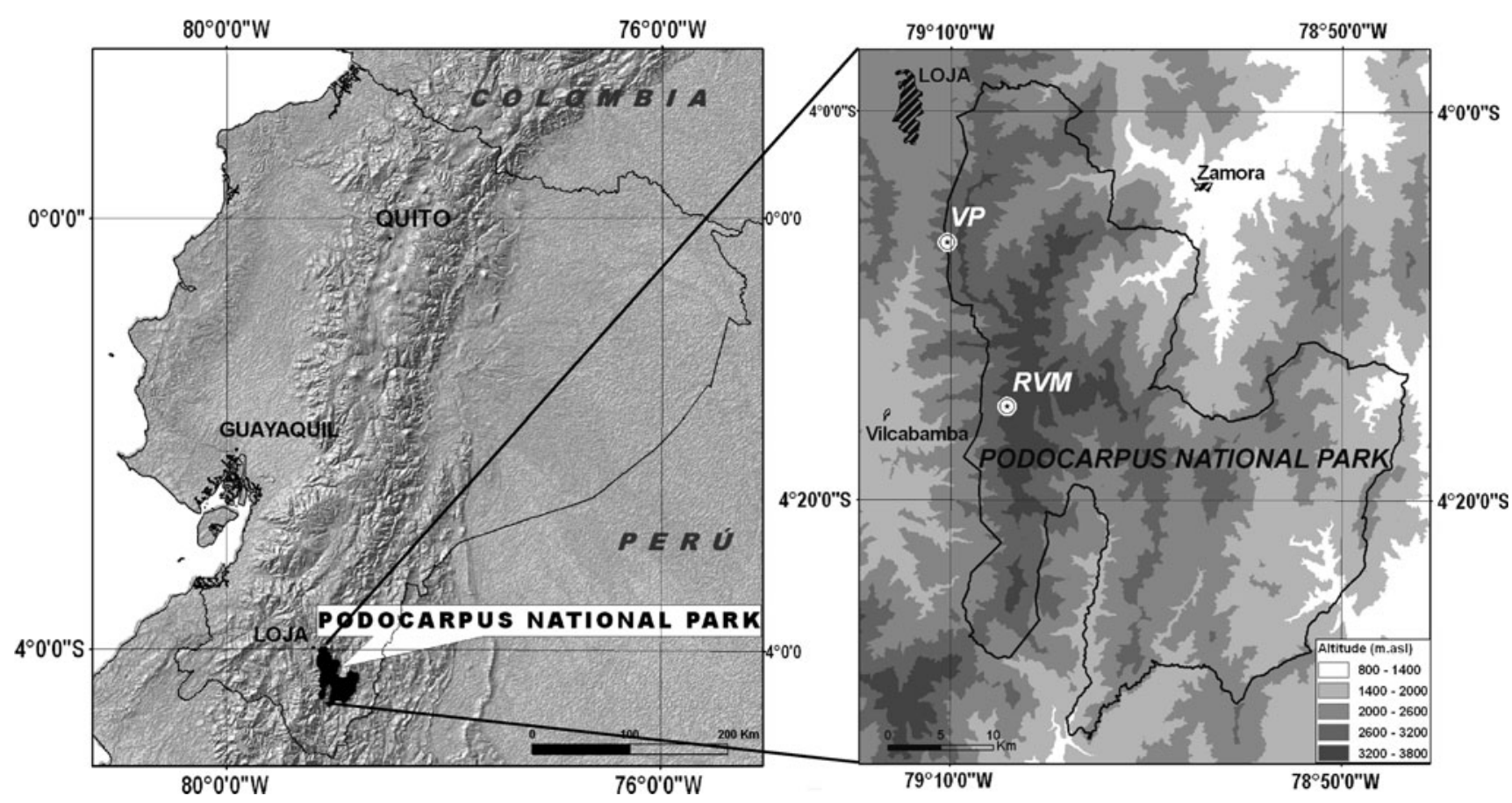

Fig. 2 Map of Ecuador showing the location of Parque Nacional Podocarpus (Podocarpus National Park) and detailed site location of the cores Rabadilla de Vaca mire (RVM) and Valle Pequeño bog (VP) in the southern Andes of Ecuador 
The windward area around Lagunas del Compadre (Cajanuma), eastwards of the main crest, receives an annual precipitation of about $5,700 \mathrm{~mm}$ and the average annual temperature is about $6.9^{\circ} \mathrm{C}$ (Emck 2007). Furthermore, the long dry period of the inter-Andean section is very pronounced in the west, while the eastern escarpment experiences only a slight dry peak restricted to November. Relative humidity is permanently high with mean values over $90 \%$, except for a short period in November (Bendix and Lauer 1992). The annual precipitation rate on the western slope ridge at $3,400 \mathrm{~m}$ is about $5,700 \mathrm{~mm}$ and the average annual temperature is about $6.9^{\circ} \mathrm{C}$ (Emck 2007). There are two weather stations located at 3,240 $\mathrm{m}$ within the UFL ecotone, one in a mixed elfin forest, the other $120 \mathrm{~m}$ away in a nearby dwarf bamboo páramo (Richter 2003).

\section{Modern vegetation}

The modern upper forest limit (UFL) in northern and central Ecuador is at ca. 3,400 $\mathrm{m}$ at La Libertad, at ca. $3,500 \mathrm{~m}$ at Atillo and at ca. 3,600 $\mathrm{m}$ at Guandera (Di Pasquale et al. 2008). Like most parts of the Cordillera Real, the lower parts of the deeply incised valley of the Río San Francisco below 2,150 m are covered by an evergreen rain forest, and the upper parts by a broad-leaved montane rain forest that extends up to the UFL between 2,700 and 3,000 $\mathrm{m}$ (Beck et al. 2008). In the Loja region, the modern UFL is at about 3,200 $\mathrm{m}$ (Richter and Moreira-Muñoz 2005). At the Paso El Tiro, $30 \mathrm{~km}$ north of the core site, the modern UFL is at ca. $2,800 \mathrm{~m}$. The movement of vegetation zones to lower elevations is probably a result of the socalled Andean depression (Bader 2007). Cores RVM and VP are located in the lower subpáramo close to the UFL. In the montane rainforest, we recognise two kinds, the lower and upper mountain rainforest. The lower montane rainforest (LMF) is present between ca. 1,800-2,150 m with an extremely diverse, two-storied tree stratum composed of trees up to 20-35 m height. Characteristic taxa are Alzatea verticillata (Alzataceae), Graffenrieda miconioides (Melastomataceae) and Myrcianthes sp. (Myrtaceae) (Bussmann 2001, 2005; Lozano et al. 2003).

The upper montane rainforest (UMF) is present between ca. 2,100-2,750 $\mathrm{m}$ and is represented by a low, monotypic formation with only one tree stratum between 5-10 m, rarely up to $15 \mathrm{~m}$. Characteristic trees are Morella pubescens (Myricaceae) and Myrsine andina (Myrsinaceae).

Two different types of modern páramo ecosystems are found within the Parque Nacional Podocarpus (PNP) region. The herbaceous páramo (páramo herbáceo) located at ca. 3,100-3,400 $\mathrm{m}$ is rich in Neurolepis nana, Calamagrostis macrophylla (Poaceae) and Niphogeton dissecta (Apiaceae). These herbs and shrubs are $0.2-1 \mathrm{~m}$ in height.
This páramo type is found on flat slopes and concave sections, as well as in ridge areas, and occurs around RVM. The shrub páramo (páramo arbustivo bajo), located at ca. 2,900-3,400 $\mathrm{m}$, is rich in Weinmannia rollottii (Cunoniaceae), Oxalis spiralis (Oxalidaceae) and Ilex andicola (Aquifoliaceae). The shrubs and herbs grow from 0.5 to $1.2 \mathrm{~m}$ height, and this páramo type is found mainly on steep slopes (Lozano et al. 2003).

The subpáramo is present between ca. 2,800-3,100 m, characterised by Puya nitida (Bromeliaceae), Brachyotum rotundifolium (Melastomataceae) and Oritrophium peruvianum (Asteraceae). Shrubs and herbs grow up to $1 \mathrm{~m}$ height, while individual shrubs can be 2-3 $\mathrm{m}$ tall (Bussmann 2001, 2005; Lozano et al. 2003).

The area is characterised by a mixture of dense elfin forest and uniform Chusquea bamboo stands, Neurolepis dwarf bamboo patches and mixed shrub páramos interspersed with tree stands, forming a complicated ecotone complex (Richter et al. 2008).

\section{Human occupation}

The first human activity in the region of Loja began around 4500 cal yrs B.P. (Guffroy 2004), but human activities may have occurred in the dry inter-Andean valley much earlier. For example, in the Sabana de Bogotá in Colombia, the presence of Amerindians could be established from 12500 yrs B.P. (14800 cal yrs B.P.) onward and possibly even before that time (Van der Hammen and Urrego 1978). Niemann and Behling (2008a) found at Paso El Tiro, located $10 \mathrm{~km}$ east of Loja, an increased fire intensity during the wetter late Holocene that suggests frequent fires of anthropogenic origin through an increased use of fire for hunting purposes and for slash and burning activities in the drier lower valleys, for example in the Loja area; fires spread into the mountains during drier phases of the year. Fire frequency decreased during the last ca. 600 years. The reduction or the absence of human activities in this region during recent centuries might be related to the dramatic decrease in human population between the 14th and 17th century. The decrease probably reflects the invasion northwards by the Inca and their occupation of the Loja region. Another probable reason for the decreased population is the arrival of Old World diseases brought by the Spaniards (Alchon 1991).

\section{Materials and methods}

\section{Coring}

Cores were taken from the central part of the two study sites, RVM and VP, using a Russian type corer. At both 
sites, $80 \mathrm{~cm}$ of core were collected. For further transport, sections of $50 \mathrm{~cm}$ length were extruded on site, covered with plastic film and placed in split PVC tubes. In the laboratory, cores were stored under cold $\left(+4^{\circ} \mathrm{C}\right)$ and dark conditions.

\section{Sample processing and analysis}

For accelerator mass spectrometer (AMS) radiocarbon dating, three $(1 \mathrm{~cm}$ thick) samples were taken from the RVM core, and two from the VP sediment core.

Forty subsamples were taken from the RVM core and 21 from VP $\left(0.25 \mathrm{~cm}^{3}\right)$ for pollen and charcoal analyses at 2 and $4 \mathrm{~cm}$ intervals, respectively. Standard pollen analytical methods were used to process the samples (Fægri and Iversen 1989). Lycopodium spores were added to each sample before treatment for calculation of pollen and charcoal concentration in grains or particles $/ \mathrm{cm}^{3}$ and influx in grains or particles $/ \mathrm{cm}^{2}$ yr. A minimum of 300 pollen grains was counted for each sample. Tree, shrub and herb pollen were included in the pollen sum, but spores and aquatic taxa were excluded. For pollen identification, we used the reference collection of the Department of Palynology and Climate Dynamics in Göttingen for neotropical taxa, and related literature (Hooghiemstra 1984; Behling 1993). The amount of charcoal particles in sediment deposits reflects the frequency of past fires. Charcoal particles $(5-150 \mu \mathrm{m})$ were counted in each sample on the pollen slides and analysed as described in the literature (Clark 1988; Clark et al. 1997, 1998).

Pollen types were grouped according to the ecosystem or habitat type for which they are most characteristic. Four main vegetation types were defined: lower montane forest, upper montane forest, subpáramo and páramo. Pollen and spore data were converted to percentages based on the pollen sums using the programs TILIA and TILIAGRAPH for calculation, drawing the diagrams and zonation (Grimm 1987). Two different pollen diagrams were generated for each core. First, a percentage diagram with the most important or representative taxa for each ecosystem, and second, a summary diagram of the pollen taxa expressed in percentages for each vegetation type (Figs. 3, 4, 5, 6). The zonation of the pollen record is based on cluster analysis by CONISS (Grimm 1987) and important changes in the pollen assemblages.

\section{Results}

\section{Stratigraphy}

The $80 \mathrm{~cm}$ long sediment for RVM core consisted mainly of dark brown peaty material. In the $80 \mathrm{~cm}$ long VP core, the sediment consisted mostly of clay. A detailed stratigraphic description of both cores is given in Table 1 .

\section{Chronology and pollen zonation}

Five AMS radiocarbon dates provide the chronology of the two sediment cores. The ages indicate that both cores cover the late Holocene period (Table 2). The dates have been calibrated using CalPal Online (Weninger et al. 2004). All dates are given as cal yrs B.P.

For RVM, three AMS radiocarbon dates show that the mire contains deposits that cover the last 2100 cal yrs B.P. The age at $47 \mathrm{~cm}$ core depth, $2796 \pm 63 \mathrm{cal} \mathrm{yrs}$ B.P. ( $2665 \pm 77$ uncal yrs B.P.), is too old and has been excluded. According to the vegetation development (see below), a disturbance of the sediments seems to be unlikely. The very low sedimentation rate of $0.075 \mathrm{~mm} / \mathrm{yr}$, calculated using the age of $2796 \pm 63 \mathrm{cal}$ yrs B.P. at $47 \mathrm{~cm}$ depth seems to be unlikely. The date must be too old as is also indicated in the age-depth graph (Fig. 7). Disturbance of the deposits cannot be completely excluded, but it is not suggested by the pollen record. Additional dating would be appropriate in order to solve these uncertainties. Based on the two calibrated radiocarbon dates used, the sedimentation rate is $0.36 \mathrm{~mm} / \mathrm{yr}$ for the lower part of the core and for the upper part $1.34 \mathrm{~mm} / \mathrm{yr}$. The rate of deposition in the lower part of the core is $31.8 \mathrm{yr} / \mathrm{cm}$ and in the upper part $19.4 \mathrm{yr} / \mathrm{cm}$ (Fig. 4).

For the VP core, two AMS radiocarbon dates (Fig. 7) show that its base has an age of $1633 \pm 57 \mathrm{cal}$ yrs B.P. (1717 \pm 47 uncal yrs в.P.). Based on the two calibrated radiocarbon dates, the sedimentation rate for the lower part of the core is $0.36 \mathrm{~mm} / \mathrm{yr}$ and for the upper part $1.34 \mathrm{~mm} /$ yr. (Fig. 7). The rate of deposition in the lower part of the core is $28.1 \mathrm{yr} / \mathrm{cm}$ and in the upper part $7.5 \mathrm{yr} / \mathrm{cm}$ (Fig. 6).

The CONISS cluster analyses and important changes in the pollen assemblages suggest four different pollen zones for RVM (RVM-I to IV) and three zones for VP (VP-I to III). The ages of each zone have been calculated by linear inter- and extrapolation.

Description of the Rabadilla de Vaca mire (RVM) pollen diagram

The percentage pollen diagram displays 27 of the most frequent and important taxa out of 123 pollen and 35 spore types recognised (Fig. 3). The identified pollen taxa are grouped into four different vegetation types and are illustrated as summary pollen diagrams (Fig. 4).

Pollen concentration of $18,300-946,000$ grains $/ \mathrm{cm}^{3}$ as well as pollen influx of 1,000-30,000 grains $/ \mathrm{cm}^{2} \mathrm{yr}$ reach the highest values in Zone RVM-I and decrease upwards 


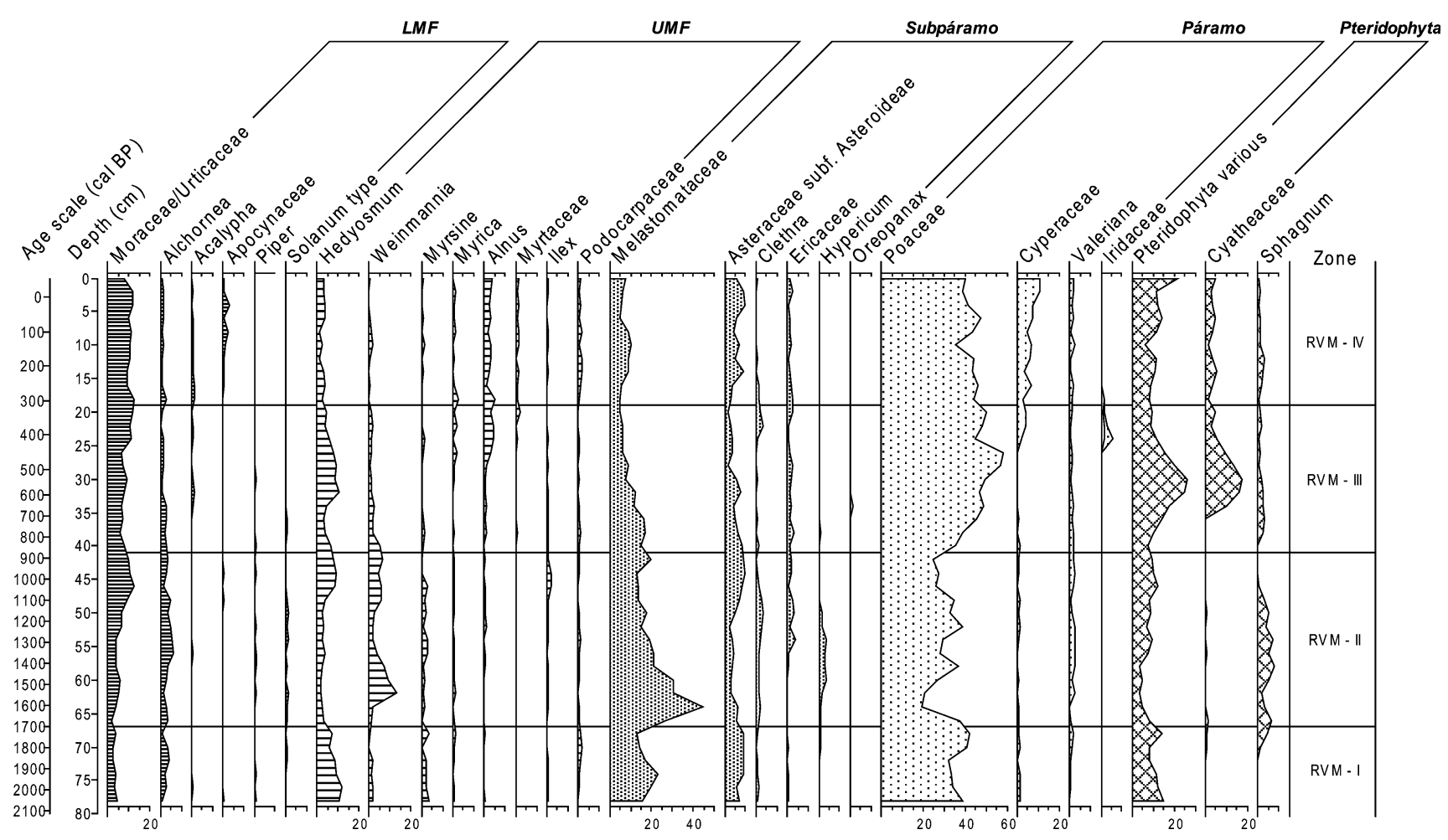

Fig. 3 Pollen percentage diagram of Rabadilla de Vaca mire (3,200 m a.s.1.) showing selected pollen and spore taxa grouped into vegetation of lower mountain forest (LMF), upper mountain orest (UMF), subpáramo, páramo and Pteridophyta

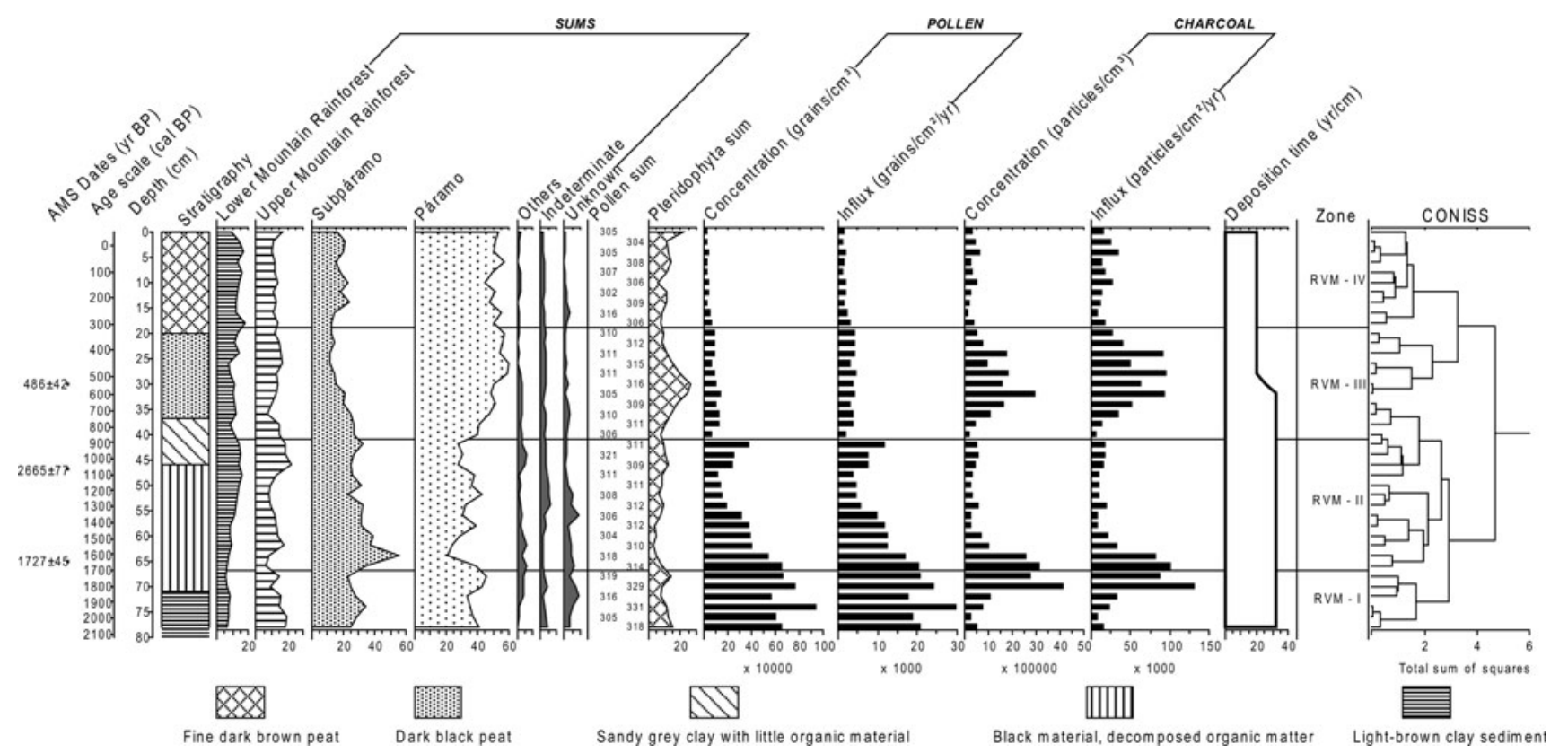

Fig. 4 Summary pollen diagram of Rabadilla de Vaca mire (3,200 m a.s.l.) showing radiocarbon dates, age scale, stratigraphy, ecological groups, pollen sum, values of pollen and charcoal concentration,

along the subsequent zones. Charcoal concentrations of $140,500-4,155,000$ grains $/ \mathrm{cm}^{3}$ and charcoal influx of 5,000$1,300,000$ particles $/ \mathrm{cm}^{2}$ yr vary markedly throughout the pollen and charcoal influx values, deposition time, zones and the CONISS dendrogram

core, with significantly higher values at the end of Zone RVM-I and the beginning of Zone RVM-II and in RVM-III (Fig. 4). 
Table 1 Stratigraphic description of the Rabadilla de Vaca mire (RVM) and the Valle Pequeño bog (VP)

\begin{tabular}{ll}
\hline Site & Depth (cm) and description \\
\hline RVM & 0-20 Fine dark brown peat with many plant remains \\
& 20-37 Dark black peat with few plant remains \\
& 37-46 Sandy grey clay with little organic material \\
& 46-71 Black material, decomposed organic material \\
& 71-80 Light-brown clay sediment \\
& 0-30 Dark brown peat with plant remains \\
& 30-44 Light grey sediment with little decomposed organic matter and fine sand \\
VP & 64-60 Dark brown clayey sediments with organic material \\
&
\end{tabular}

Zone RVM-I (80-67 cm, ca. 2100-1720 B.P., six samples)

This zone is represented by low percentages of lower montane forest (LMF) taxa (6-8\%), mostly Moraceae/Urticaceae $(2-4 \%)$ and Alchornea $(1-4 \%)$. The percentages of upper montane forest taxa (UMF) are markedly higher (9-19\%), mainly Hedyosmum (6-12\%) and low values of Myrsine (0-4\%), Weinmannia and Podocarpaceae (0-2\%). Pollen of subpáramo vegetation ranges between 23 and $34 \%$, and is dominated by pollen of Melastomataceae (13$20 \%$ ) and Asteraceae subfamily Asteroideae (6-9\%). Páramo vegetation is represented by a large proportion of pollen (33-46\%), of which Poaceae is the most frequent (32-42\%). Cyperaceae and Valeriana (1-2\%) occur in very low values. Spores of Pteridophyta are present in proportions between $8-15 \%$. At the end of this zone, Sphagnum is represented with a value of $4 \%$.

Zone RVM-II (67-41 cm, ca. 1720-880 B.P., 13 samples)

Compared with RVM-I, LMF pollen is still represented in low percentages, but increases markedly at the middle of the zone $(6-15 \%)$ due to the increase of Moraceae/Urticaceae (2-12\%) and Alchornea (1-7\%). Pollen from UMF continues to be frequent (6-22\%). Pollen of Hedyosmum decreases compared with the previous zone, but increases at the end of the zone from 1 to $9 \%$. Weinmannia pollen (1-13\%) increases significantly at the beginning and increases at the end of this zone. Myrsine pollen (0-3\%) remains continuously low. The subpáramo vegetation group is represented by the highest values (23-55\%), especially at the beginning of the zone, mostly by the marked increase of Melastomataceae (13-44\%). Asteraceae subf. Asteroideae decreases slightly and increases again at the end of the zone (2-10\%). Pollen of Clethra (0-3\%), and later Ericaceae and Hypericum (both between 0 and 4\%), are more frequent in this zone than in Zone RVM-I. The proportion of páramo taxa $(21-43 \%)$ is lower, due to the decrease of Poaceae pollen (38-19\%). Spores of Pteridophyta remain with no significant changes (3-12\%). Sphagnum spores increase and are well represented $(0-8 \%)$ in this zone.

Zone RVM-III (41-19 cm, ca. 880-310 B.P., 11 samples)

The LMF pollen representation is similar to that in the previous zone $(8-14 \%)$. Moraceae/Urticaceae pollen remains relatively stable during this period $(5-12 \%)$, while Alchornea pollen decreases slightly $(0-3 \%)$. The UMF group decreases from 7 to $16 \%$, Hedyosmum pollen increases (3-10\%). Weinmannia pollen decreases at the beginning and Morella (0-2\%) as well as Alnus (0-5\%) increase at the end of the zone. Pollen of subpáramo vegetation decreases markedly from 27 to $12 \%$ at the end of this zone, mainly in Melastomataceae (17-5\%) and Asteraceae subf. Asteroideae (8-2\%), while Clethra pollen $(0-5 \%)$ is now rare, but increases at the end of the zone. Ericaceae pollen continues to be relatively stable with low values (1-3\%). Páramo taxa increase markedly at the

Table 2 List of AMS radiocarbon dates from Rabadilla de Vaca mire (RMV) and Valle Pequeño bog (VP)

\begin{tabular}{lllccc}
\hline Core & Lab. number & Depth $(\mathrm{cm})$ & ${ }^{14}$ C-age $($ yrs B.P. $)$ & Calendar age $^{\text {a }}\left(\mathrm{cal}_{\text {yrs B.P. }}\right)$ & $1-\sigma$ range $(\mathrm{cal}$ yrs B.P.) \\
\hline RVM & Erl-11391 & 30 & $486 \pm 42$ & 530 & $512-544$ \\
& Erl-11033 & 47 & $2665 \pm 77$ & 2800 & $2733-2859$ \\
& Erl-11034 & 65 & $1727 \pm 45$ & 1640 & $1596-1684$ \\
VP & Erl-11027 & 27 & $156 \pm 44$ & 150 & $37-253$ \\
& Erl-11028 & 80 & $1717 \pm 47$ & 1640 & $1576-1690$ \\
\hline
\end{tabular}

${ }^{\text {a }}$ Calibration of ${ }^{14} \mathrm{C}$ ages is based on CalPal Online (CalPal 2007 HULU curve). The calibrated ages stand for the mean probability of the $1-\sigma$ upper and lower age ranges 
beginning of the zone (40-59\%), dominated by Poaceae pollen $(36-58 \%)$, which has the highest values in this period. Cyperaceae $(0-4 \%)$ and Iridaceae pollen $(0-2 \%)$ increase at the end of the zone. Pteridophyta spores reach the highest proportion (7-27\%) in the middle of this zone. Sphagnum spores (0-3\%) are less frequent.

\section{Zone RVM-IV (19-0 cm, ca. 310 B.P.-present-day, 10 samples)}

The representation of LMF pollen (10-18\%) increases slightly with higher values of Moraceae/Urticaceae (9$13 \%)$ and Apocynaceae $(0-3 \%)$. The proportion of UMF taxa $(10-16 \%)$ remains stable. However, pollen of $\mathrm{He}$ dyosmum decreases (4-1\%). Myrtaceae and Podocarpaceae remain low (0-2\%), Alnus decreases slightly compared to the upper part of the previous zone from 5 to $2 \%$, but is still high compared to other zones in the record. Pollen of subpáramo vegetation (13-24\%) increases slightly through the higher representation of Melastomataceae (5-10\%) and Asteraceae subf. Asteroideae pollen (3-10\%). Páramo taxa are well represented, but decrease slightly in this zone $(55-45 \%)$ by the slight decrease of Poaceae $(47-40 \%)$, while Cyperaceae pollen increases from 3 to $11 \%$. Valeriana pollen shows values between 1 and 3\%. Representation of Pteridophyta spores remains stable (6-27\%). Sphagnum spores still occur in low frequencies (1-3\%).

Description of the Valle Pequeño (VP) pollen diagram

The percentage pollen diagram displays 25 of the most frequent and important taxa out of 128 pollen and 29 spore types recognised (Fig. 5). The identified pollen taxa are grouped into four different vegetation types as illustrated in the summary pollen diagram (Fig. 6).

Pollen concentrations of 280,000-4,850,000 grains $/ \mathrm{cm}^{3}$ reach the highest values in Zone VP-I and pollen influx of $10,000-1,720,000$ grains $/ \mathrm{cm}^{2}$ yr has high values in VP-I and VP-III. Charcoal concentrations of 208,000-1,490,000 particles $/ \mathrm{cm}^{3}$ show the highest values in VP-I and VP-III, and charcoal influx of 7,400-181,700 particles $/ \mathrm{cm}^{2} \mathrm{yr}$ with markedly higher values in Zone VP-III (Fig. 6).

Zone VP-I (80-58 cm, ca. 1630-1020 B.P., six samples)

Pollen from lower montane forest (LMF) taxa is poorly represented $(2-5 \%)$. The most frequent pollen is from Moraceae/Urticaceae $(0-4 \%)$. Proportions of upper montane forest (UMF) taxa are notably higher (36-49\%) with pollen of Hedyosmum (28-44\%) and low values of Myrsine (1-4\%), Alnus and Weinmannia (1-2\%). Pollen of subpáramo vegetation ranges between 23 and $28 \%$, dominated by Melastomataceae (13-21\%). Much less frequent is pollen of the Muehlenbeckia type (3-6\%), Clethra (0-4\%), Ericaceae and Asteraceae subf. Asteroideae (both between 0 and $2 \%$ ). Páramo vegetation is represented in markedly higher proportion $(21-30 \%)$, dominated by Poaceae (19$24 \%)$ and Cyperaceae $(0-5 \%)$. Spores of Pteridophyta are represented in low proportions (1-6\%).

Zone VP-II (58-30 cm, ca. 1020-230 B.P., seven samples)

LMF pollen increases from 1 to $8 \%$, due to the increase of Moraceae/Urticaceae (0-4\%) and pollen of Acalypha, Alchornea and Solanum type (0-2\%). UMF pollen (34-48\%) continues to be dominant, but decreases at the end of this zone, primarily due to changes in Hedyosmum pollen (4229\%). Values of Weinmannia (0-3\%), Alnus, Myrsine and Ilex pollen (0-2\%) remain low. The subpáramo group is well represented (24-39\%) compared to the previous zone, mainly through the increase of Melastomataceae pollen (19-34\%). The values of the páramo group remain relatively stable (19-32\%), but the variation of Poaceae pollen is stronger (13-30\%). Representation of Pteridophyta spores remains stable $(3-7 \%)$.

\section{Zone VP-III (30-0 cm, ca. 230-60 B.P., eight samples)}

Representation of LMF pollen decreases slightly (1-5\%) compared to VP-II from the slightly lower frequency of Moraceae/Urticaceae pollen (1-3\%) and other taxa. The sum of UMF pollen decreases (39-32\%), due to a lower representation of Hedyosmum (33-25\%). Subpáramo taxa are well represented (26-39\%) and increase slightly compared to Zone VP-II. Pollen of páramo taxa increases slightly (23-34\%) primarily from Poaceae (19-29\%). Spores of Pteridophyta do not show marked changes compared to Zone VP-II (3-7\%).

\section{Interpretation and discussion}

Vegetation changes during the late Holocene

The records from the Rabadilla de Vaca mire (RVM) and Valle Pequeño (VP) cores reflect the vegetation changes on the drier western slopes of the Podocarpus National Park from 2100 в.P. and 1630 в.Р., respectively. The composition of the pollen assemblages on both sites was similar, but representation of the taxa differed due to different local topographic conditions, since the RVM site lies on a slope and VP is in a small valley. In spite of the slightly higher elevation of the VP site (44 m), upper montane forest (UMF) was strongly represented, in particular by Hedyosmum, compared to the RVM site. This was probably due to 


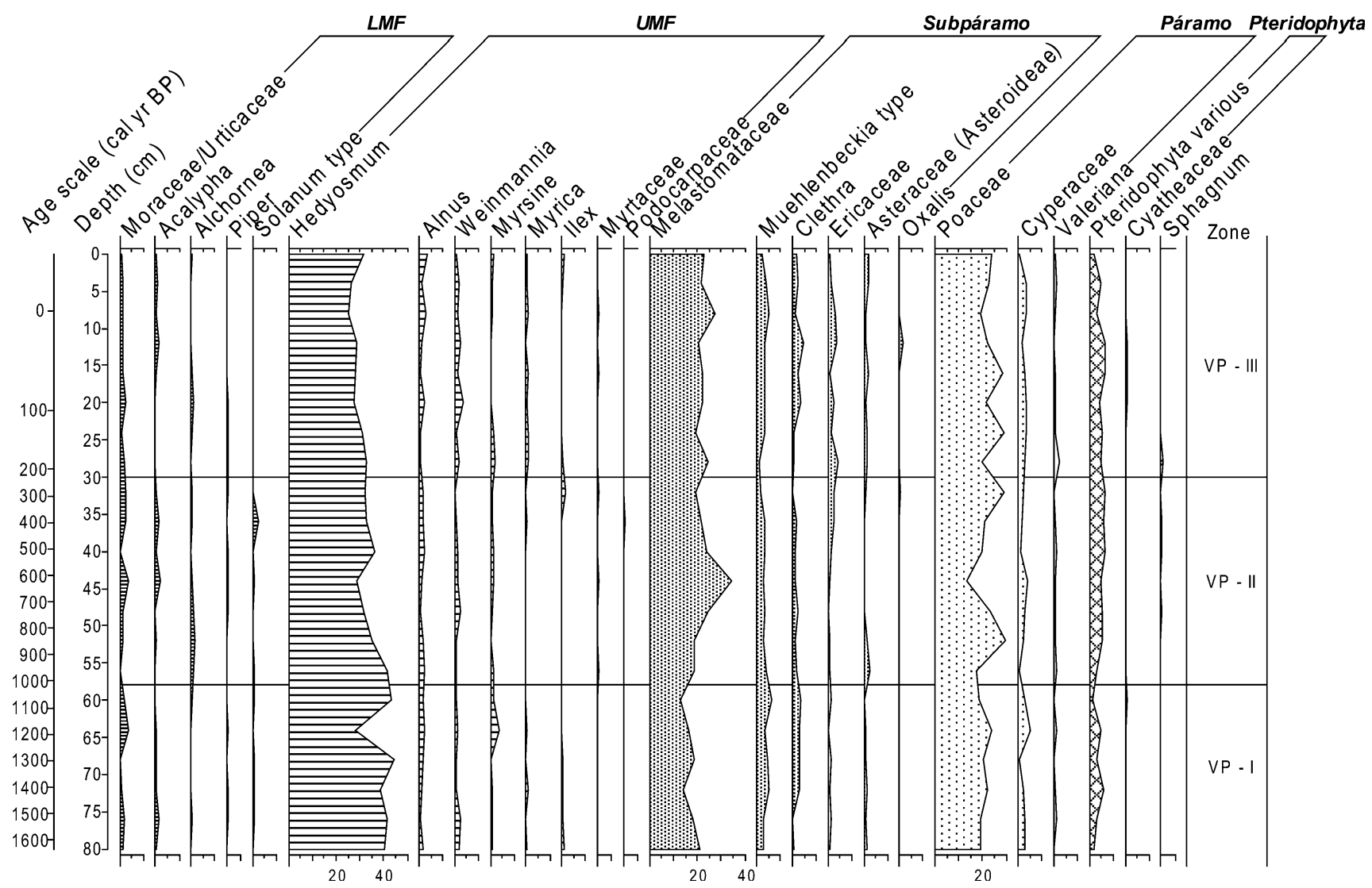

Fig. 5 Pollen percentage diagram of Valle Pequeño bog (3,244 m a.s.1.) showing selected pollen and spore taxa grouped into vegetation of lower mountain forest (LMF), upper mountain forest (UMF), subpáramo, páramo and Pteridophyta

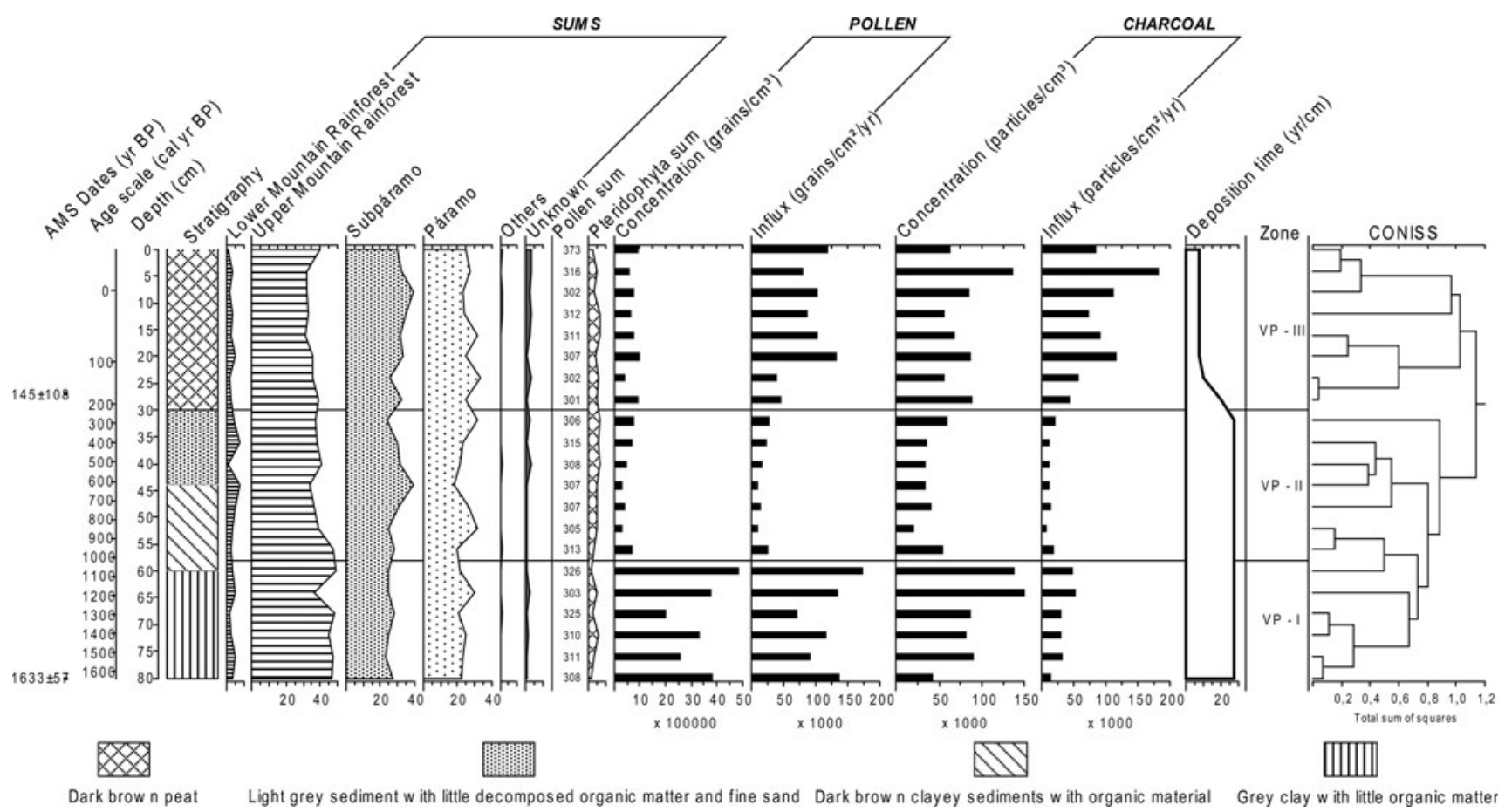

Fig. 6 Summary pollen diagram of Valle Pequeño bog (3,244 m a.s.1.) showing radiocarbon dates, age scale, stratigraphy, ecological groups, pollen sum, pollen values and charcoal concentrations, pollen and charcoal influx values, deposition time, zones and the CONISS dendrogram 


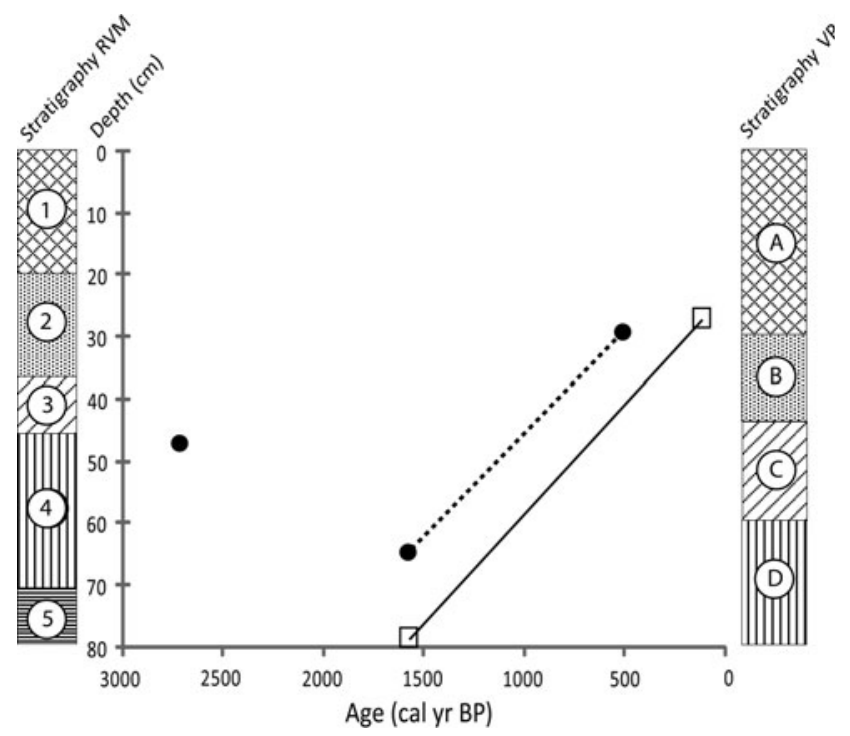

Fig. 7 Age-depth model and stratigraphy of the sediment of Rabadilla de Vaca mire (black circles) and Valle Pequeño bog (white squares) based on three and two calibrated radiocarbon dates, respectively. Stratigraphic description: 1 , fine dark brown peat with many plant remains; 2 , dark black peat with few plant remains; 3 , sandy grey clay with little organic material; 4, black material, decomposed organic matter; 5 , light-brown clay sediment; $A$, dark brown peat with plant remains; $B$, light grey sediment with little decomposed organic matter and fine sand; $C$, dark brown clayey sediments with organic material; $D$, grey clay with little organic matter

the valley conditions around VP, which might be locally favourable for Hedyosmum.

The results of the RVM record show that from ca. 2100 to 1720 B.P. (Zone RVM-I), lower montane forest (LMF) was less represented due to the lower frequency of Moraceae/Urticaceae, and UMF was most abundant due to the higher occurrence of Hedyosmum. Lower values of Poaceae and Cyperaceae than at present show that there was less páramo vegetation in the area, while subpáramo was more strongly represented, as indicated by increased Melastomataceae.

The period from ca. 1720 to 880 B.P. is included in both records, Zone RVM-II and Zone VP-I and the lower part of Zone VP-II. The RVM record shows no marked changes in the proportion of the LMF; however, in the second part of this period, from 1200 B.P. to the present day, Moraceae/ Urticaceae became more abundant. This period also shows a stronger occurrence of Weinmannia in the UMF compared to the previous and subsequent periods.

At the beginning of this period, a marked increase of subpáramo taxa in the RVM area is indicated by increased Melastomataceae. Páramo was partly replaced by subpáramo and UMF taxa, and as a consequence, there were fewer Poaceae in the study area. In the VP record, no marked vegetational changes can be detected during this period.
From ca. 880 to 310 B.P., in Zone RVM-III the proportion of the LMF and UMF remained relatively stable as in VP. Parámo vegetation expanded continuously due to the spread of Poaceae, while subparámo vegetation decreased, as indicated by the continuously lower occurrence of Melastomataceae in this area. In Zone VP-II upper part, first a slight increase and then a slight decrease of subpáramo, is indicated especially by the increasing and decreasing representation of Melastomataceae.

From ca. 310 в.P. until present, in the RVM and VP areas the proportion of the LMF and UMF still remained relatively stable. One important difference between the two pollen records is that Alnus, which was so far rare, became quite frequent in the UMF of the RVM area. The páramo ecosystem was dominant in the RVM area, reflected by the still frequent occurrence of Poaceae and a stronger distribution of Cyperaceae. The area of subpáramo was relatively small. In the Valle Pequeño area, the different vegetation types remained relatively stable during this period (Zone VP-III).

Summarising, both records reflect relatively stable vegetation over the past 2100 and 1660 years, respectively, compared to the modern vegetational conditions as indicated by the pollen assemblages of the top samples of the sediment cores. With the exception of some minor fluctuations, the composition and the proportion of the LMF and the UMF remained stable. However, some noticeable vegetational changes occurred in the extent of subpáramo and páramo vegetation, in particular in the RVM record, where subpáramo had a stronger representation between 2100 and 880 в.P., followed by a period of marked páramo vegetation expansion between 880 and 310 B.P., and a period of stronger páramo representation during the last 310 yrs B.P. In the VP record the proportion of different ecosystems was relatively stable, with the exception of a slight decrease of the UMF and a slight increase of the subpáramo taxa, suggesting a lowering of the upper forest limit (UFL).

Fire and human impact during the late Holocene

The charcoal records of the RVM and VP sites indicate that fires occurred in the region throughout the late Holocene. In the RVM core two periods of higher fire frequency, best reflected in the charcoal influx data, are indicated between 1800 and 1600 B.P. in the upper part of Zone RVM-II and between 600 and 400 в.P. in Zone RVM-III. In the VP core only one period with increasing higher fire frequency is found from 310 to 60 в.P. in Zone VP-III. The charcoal records from both sites, located on the western slopes of the Podocarpus National Park about $16.5 \mathrm{~km}$ apart, indicate that frequent fires did not occur synchronously at both sites. This might suggest that frequent fires have been caused by human activities rather than naturally, due to drier 
conditions and lightning. However, the different settings of the sites may also play a certain role.

Further evidence of human activity in the region might be reflected by the higher values of Alnus in RVM from ca. 480 B.P. and in VP since ca. 50 yrs. Alnus is a pioneer tree which colonises wet bare ground following landslides (Marchant et al. 2002) and also occurrs on wet soils along drainage systems (Weng et al. 2004).

Upper forest line changes and the role of fire and climate during the late Holocene

Upper Forest Line dynamics should be mainly reflected by fluctuations in the proportion of upper montane forest (UMF) and subpáramo vegetation. The vegetation reconstruction of both sites indicates that the proportions of the UMF and subpáramo were relatively stable during the recorded period. However, the VP record indicates a trend of decreasing UMF and increasing subpáramo, pronounced since about 230 в.P., at the end of Zone VP-II. This might reflect a slight lowering of the upper forest limit. In the $\mathrm{RVM}$ record a relatively stable proportion of UMF can be observed with some fluctuations, but there are some more distinct changes to higher proportions of the subpáramo, particularly between 880 to 310 в.P. in Zone RVM-II. This dominant representation of subpáramo was mainly related to the decrease of páramo vegetation. However, the expansion of Weinmannia during the period between 1720 and 880 B.P. may indicate an expansion of the UMF and therefore a raising of the upper forest limit during that time.

Important questions are what controlled the UFL dynamics during the late Holocene period, whether fires were natural or anthropogenic and if climate was an important factor.

Comparing vegetation and fire records of the two sites, it is evident that frequent fires favoured the expansion of grass páramo at the expense of the subpáramo. This is best indicated in the RVM record, where the decrease of fire frequency in RVM-II favoured the expansion of subpáramo and Weinmannia in the UMF, and the increase of fire in Zone RVM-III favoured the expansion of grass páramo and a decrease of Weinmannia. In the VP record, the minor decrease of the UMF and the increase of subpáramo since about $230 \mathrm{yrs}$ B.P. at the end of Zone VP-II is also a period with a higher fire frequency. This also suggests that the increase of fire frequency played an important role in the lowering of the upper forest limit. Consequently, climate change and its role in controlling the UFL cannot be disclosed through these two late Holocene records, due to the relatively strong correlation between vegetation and fire dynamics.

Overall, it is necessary to consider that charcoal influxbased frequency of fires in the two records is relatively low compared to other records from the region. In the El Tiro record, Niemann and Behling (2008a) show that charcoal influx increased during the mid Holocene and in particular during the late Holocene, before decreasing significantly after 500 в.Р. (Fig. 1). The increase of fire frequency, even during the wet late Holocene period, probably indicates that the fires were of human origin. Both sites differ slightly and fires may have had different local effects, but a markedly different fire frequency may also suggest changes in human activity. Vegetational changes, such as the increase of Moraceae/Urticaceae in the RVM record since ca. 1200 B.P. and the replacement of some areas of grass páramo by subpáramo and UMF with Weinmannia between ca. 1600 and 880 в.P. might reflect an increase in temperature. However, due to the strong correlation between vegetation changes and fire it is difficult to address the role of climate in changes to the upper forest limit. Additional studies of pollen records at the UFL in places far from human settlements are needed to clarify this issue.

Comparison with other records from the Parque Nacional Podocarpus and from other sites in the Andes

Four other records from the Parque Nacional Podocarpus (PNP) region are important for comparison of the upper forest limit (UFL) (Fig. 1). The first site, Laguna Rabadilla de Vaca (RV) at 3,312 $\mathrm{m}$ and about $1 \mathrm{~km}$ from RVM and about $110 \mathrm{~m}$ higher up, is located in the páramo vegetation zone (Niemann et al. 2009). Since ca. 3700 yrs, the dominance of herbaceous páramo at this site reflects cooler climatic conditions than during the previous mid and early Holocene from 3700 to 11700 B.P. Sediment analysis by XRF scanning indicates a decrease of $\mathrm{Si}$ and $\mathrm{Ti}$ suggesting drier conditions during the whole late Holocene, compared to the late middle Holocene period. The new results for RVM show an expansion of páramo vegetation from 880 B.P. until the present day, which coincides with the Laguna $\mathrm{RV}$ findings. In the RVM record, two periods of high fire frequency are recorded between 1800-1600 and 600-400 B.P., which show that burning associated with humans controlled the UMF vegetation and favoured expansion of páramo vegetation; meanwhile, in the record from Laguna $\mathrm{RV}$ the very high charcoal influx may suggest uncontrolled burning caused by humans near the study site at ca. 3600 B.P.

The second record comes from El Tiro at $2,810 \mathrm{~m}$, located about $14 \mathrm{~km}$ north of VP (Niemann and Behling 2008a). Pollen data show that UMF decreased and the modern subpáramo vegetation with high Melastomataceae became established and was relatively stable since ca. 3300 yrs. This shows vegetation change because of wetter and probably cooler conditions than those of the early-mid Holocene from 11200 to 8900 B.P. Fires increased after 
8000 в.P., and became even more frequent after 3500 в.Р., suggesting that they were caused by humans even during this wetter period. During the last 500 yrs, fire frequency decreased, probably due to the decrease of the human population (Niemann and Behling 2008b). The upper forest limit at Paso El Tiro is at ca. 2,800 m, thus ca. $400 \mathrm{~m}$ lower than at RVM and VP.

The third record is Cerro Toledo at 3,150 m, located $13 \mathrm{~km}$ south of RVM, where since ca. 1800 B.P. a slight decrease in páramo could indicate a change to somewhat warmer temperatures. The highest temperatures probably occurred between 9300 and 8500 B.P. changing to somewhat cooler conditions after 1800 B.P. (Brunschön and Behling 2009).

The fourth record is Laguna Zurita at 2,590 m, ca.10 km north of Loja, where XRF data of a sediment core show wet climatic conditions before ca. $790 \mathrm{cal}$ yrs B.P. and drier conditions between ca. 790 and 480 B.P. (Niemann and Behling 2010).

In Pantano de Pecho (Fig. 1) at 3,870 m, a Poaceaedominated herbaceous páramo occurred from ca. 3700 в.Р. until modern times, reflecting cooler climatic conditions compared to the mid Holocene between 8990 and 3680 в.P. (Wille et al. 2002). However, after ca. A.D. 1595 (A.D. 1640), increasing amounts of charcoal particles suggest an intensification of human impact related to the Spanish conquest in this area around A.D. 1540 (Wille et al. 2002).

Based on the results from Lago Surucucho at $3,180 \mathrm{~m}$, $165 \mathrm{~km}$ north of VP, Colinvaux (1997) stated that forest could be established at 3,180 m and that the UFL was at a similar altitude as in the Parque Nacional Podocarpus area (Fig. 1). Fires were very frequent at Lago Surucucho between 2000 and 600 B.P., suggesting a continuous change of UFL during the past. According to the pollen diagram in VP, the signal of upper forest limit changes is much less obvious, suggesting that the UFL was much more stable in the so-called Andean depression compared to areas to the north of the Andean regions.

Di Pasquale et al. (2008) showed that in Guandera, northern Ecuador, the UFL had moved up to its present position at 3,600 $\mathrm{m}$ only during the late Holocene, after ca. 5850 в.P., and that the UFL may have been situated between 3,600 $\mathrm{m}$ and 3,800 $\mathrm{m}$ at some time after ca. 4900 B.P., or it may never have been higher than it is today (Fig. 1). These results differ from palaeoecological reconstructions of Llanos Orientales in Colombia and Rupununi savanna in Guyana, which suggest a rapid UFL rise during the Pleistocene-Holocene transition (Van der Hammen 1974; Flenley 1979; Di Pasquale et al. 2008). They also contradict the hypothesis that fires caused by humans have destroyed large areas of forest which had grown above the modern UFL. Instead, páramo fires have probably contributed to the slow rates of UFL rise during the Holocene (Di Pasquale et al. 2008).

Bakker et al. (2008) also demonstrated that in Guandera at $3,400 \mathrm{~m}$ fires became more frequent in the region from 2160 to ca. 910 B.P. From ca. 910 to ca. 520 в.P., the UFL moved to $3,250-3,300 \mathrm{~m}$, and fire became increasingly frequent but the particles were mostly small. From 520 B.P. to the present day, the UFL moved up some $200-3,600 \mathrm{~m}$. The abundance of charcoal particles further increased during this period, indicating that fires became more frequent. This supports the interpretation that human impact became an important factor during the last six centuries. During recent decades, values of arboreal taxa have remained constant. However, shrubs in particular decreased, while grassy vegetation increased. This change in composition suggests that the subalpine rainforest (SARF) is disappearing, possibly as a result of burning, as charcoal remains abundant.

Results from Pantano de Pecho in the central Ecuadorian páramo at $3,870 \mathrm{~m}$, show that during the past six centuries the UFL has moved to between 3,400 and 3,650 m (Wille et al. 2002). The results from the Ecuadorian records of Guandera and Pantano de Pecho and the Colombian pollen record of Llano Grande-II show that the UFL could have had its highest position at $3,700 \mathrm{~m}$ from 4000 to 3000 uncal yrs в.P. The UFL subsequently descended and reached its lowermost position between 1100 and 600 uncal yrs B.P. (Bakker et al. 2008).

\section{Conclusions}

Pollen and charcoal records from Rabadilla de Vaca Mire and Valle Pequeño have allowed the reconstruction of vegetation, fire and upper forest limit changes in the Parque Nacional Podocarpus during the last ca. 2100 yrs and 1630 B.P., respectively. The RVM record shows that the upper forest limit has been relatively stable in the study areas during the late Holocene. Changes between the proportion of upper montane forest and subpáramo vegetation probably reflect changes in the upper forest limit from 2100 в.P., indicating that the limit dividing forest from páramo was higher during the period between 1600 to 880 B.P. and became lower after about 880 B.P., becoming more stabilised after about 310 в.P.

The marked increase of fire frequency at RVM between 1800 and 1600 B.P. and 600 and 400 B.P. suggests that ecosystems in the study area were affected by human activity even under wetter conditions. For VP, the stability of the upper montane forest suggests no clear evidence of changes to the upper forest limit, although a slight change during recent decades has been detected. The higher fire 
frequency from ca. 230 B.P. suggest that human activities have had some impact on this area.

Comparing the vegetation and fire records of the two sites, it is evident that frequent fires favoured the expansion of grass páramo vegetation and curtailed the expansion of subpáramo vegetation and upper montane forest. Because fire probably played an important role in controlling changes to the upper forest limit since ca. 1800 B.P., it is difficult to detect whether climate change played an important role in these changes during this period.

Acknowledgements The authors thank the members of the research unit FOR 816 and the San Francisco Research Station team for logistic support of our work. We acknowledge the scientific discussions and suggestions of Michael Richter (Erlangen) and Jürgen Homeier (Göttingen). Thanks also to Corinna Brunschön for support and discussions during this research. The Deutsche Forschungsgemeinschaft (DFG) research unit FOR816 "Biodiversity and sustainable management of a megadiverse mountain ecosystem in southern Ecuador" and the "Bundesministerium für wirtschaftliche Zusammenarbeit und Entwicklung (BMZ)" are thanked for their financial support (BE 2116/8-1) of this work.

Open Access This article is distributed under the terms of the Creative Commons Attribution Noncommercial License which permits any noncommercial use, distribution, and reproduction in any medium, provided the original author(s) and source are credited.

\section{References}

Alchon SA (1991) Native society and disease in colonial Ecuador. Cambridge University Press, Cambridge

Bader MY (2007) Tropical alpine tree lines; how ecological processes control vegetation patterning and dynamics. Doctoral thesis, Wageningen University

Bakker J, Moscol Olivera M, Hooghiemstra H (2008) Holocene environmental change at the upper forest line in northern Ecuador. Holocene 18:877-893

Beck E, Makeschin F, Haubrich F, Richter M, Bendix J, Valarezo C (2008) The ecosystem (Reserva Biológica San Francisco). In: Beck E, Bendix J, Kottke I, Makeschin F, Mosandl R (eds) Gradients in a tropical mountain ecosystem of Ecuador, (Ecol Stud 198). Springer, Berlin, pp 1-14

Behling H (1993) Untersuchungen zur spätpleistozänen und holozänen Vegetations- und Klimageschichte der tropischen Küstenwälder und der Araukarienwälder in Santa Catarina (Südbrasilien). Diss Bot 206, Cramer, Berlin

Behling H, Hooghiemstra H (1998) Late Quaternary paleoecology and paleoclimatology from pollen records of the savannas of the Llanos Orientales in Colombia. Palaeogeogr Palaeoclimatol Palaeoecol 139:251-267

Behling H, Hooghiemstra H (2000) Holocene Amazon rain forestsavanna dynamics and climatic implications: high resolution pollen record Laguna Loma Linda in eastern Colombia. J Quat Sci 15:687-695

Bendix J, Lauer W (1992) Die Niederschlagsjahreszeiten in Ecuador und ihre klimadynamische interpretation. Erdkunde 46:118-134

Bendix J, Rollenbeck R (2004) Gradients of fog and rain in a tropical cloud forest of southern Ecuador and its chemical composition. In: Proceedings of the third international conference on fog, fog collection and dew, 11-15 October, Cape Town. Available on CD-ROM, H7

Bendix J, Rollenbeck R, Richter M, Fabian P, Emck P (2008) Climate. In: Beck E, Bendix J, Kottke I, Makeschin F, Mosandl $\mathrm{R}$ (eds) Gradients in a tropical mountain ecosystem of Ecuador (Ecological studies 198). Springer, Berlin, pp 63-73

Brunschön C, Behling H (2009) Late Quaternary vegetation, fire and climate history reconstructed from two cores at Cerro Toledo, Podocarpus National Park, south-eastern Ecuadorian Andes. Quat Res 72:388-399

Brunschön C, Haberzettl T, Behling H (2010) High-resolution studies on vegetation succession, hydrological variations, anthropogenic impact and genesis of a subrecent lake in southern Ecuador. Veget Hist Archaeobot 19:191-206

Bussmann RW (2001) The montane forest of Reserva Biológica San Francisco (Zamora-Chinchipe, Ecuador). Vegetation, zonation and natural regeneration. Erde 132:9-25

Bussmann RW (2005) Bosques andinos del sur de Ecuador, clasificación, regeneración y uso. Rev Peru Biol 12:203-216

Clark JS (1988) Stratigraphic charcoal analysis on petrographic thin sections: application to fire history in Northwestern Minnesota. Quat Res 30:81-91

Clark JS, Cachier H, Goldammer JG, Stocks BJ (1997) Sediment records of biomass burning and global change. Springer, Berlin

Clark JS, Lynch J, Stocks BJ, Goldammer JG (1998) Relationships between charcoal particles in the air and sediments in westcentral Siberia. Holocene 8:19-29

Colinvaux PA (1997) Glacial and postglacial pollen records from the Ecuadorian Andes and Amazon. Quat Res 48:69-78

Di Pasquale G, Maziano M, Impagliazzo S, Lubritto C, De Natale A, Bader M (2008) The Holocene treeline in the northern Andes (Ecuador): first evidence from soil charcoal. Palaeogeogr Palaeoclimatol Palaeoecol 259:17-34

Dodson CH, Gentry AH (1991) Biological extinction in Western Ecuador. Ann Mo Bot Gard 78:273-295

Ellenberg H (1958) Wald oder Steppe? Die natürliche Pflanzendecke der Anden Perus, parts I, II. Die Umschau in Wissenschaft und Technik 645-648, 679-681, Brönners Druckerei Beindenstein, Frankfurt

Emck P (2007) A climatology of south Ecuador-with special focus on the major Andean ridge as Atlantic-Pacific climate divide. Dissertation, Universität Erlangen-Nürnberg

Fægri K, Iversen J (1989) Textbook of pollen analysis (4th edn by Fægri K, Kaland PE and Krzwywinski K). Wiley, Chichester

Flenley JR (1979) The equatorial rain forest: a geological history. Butterworths, London

Grimm EC (1987) CONISS: a Fortran 77 program for stratigraphically constrained cluster analysis by the method of the incremental sum of squares. Comput Geosci 13:13-35

Guffroy J (2004) Catamayo precolombino. Investigaciones arqueologicas en la provincia de Loja (Ecuador). IRD editions, Paris

Hansen BCS, Rodbell DT, Seltzer GO, Leon B, Young KR, Abbott M (2003) Late-glacial and Holocene vegetational history from two sites in the western Cordillera of southwestern Ecuador. Palaeogeogr Palaeoclimatol Palaeoecol 194:79-108

Hooghiemstra H (1984) Vegetational and climatic history of the high plain of Bogotá, Colombia: a continuous record of the last 3.5 million years. Diss Bot 79, Cramer, Vaduz

IPCC (2007) Climate change 2007: the physical science basis (summary for policy makers). IPCC, Geneva

Islebe GA, Hooghiemstra H (1997) Vegetation and climate history of montane Costa Rica since the last glacial. Quat Sci Rev 16: 589-604

Kessler M (2002) The "Polylepis problem": where do we stand? Ecotropica 8:97-110 
Laegaard S (1992) Influence of fire in the grass páramo vegetation of Ecuador. In: Balslev H, Luteyn JL (eds) Páramo. An Andean ecosystem under human influence. Academic Press, London, pp $151-170$

Litherland M, Aspen JA, Jemielita RA (1994) Metamorphic belts in Ecuador. Overseas Mem Br Geol Surv 11:1-147

Lozano P, Delgado T, Aguirre Z (2003) Estado actual de la flora endémica exclusiva y su distribución en el occidente del Parque Nacional Podocarpus. Fundación Funbotánica, Herbario y Jardín Botánico "Reinaldo Espinosa". Loja, Ecuador

Marchant R, Behling H, Berrio JC, Cleef A, Duivenvoorden J, Hooghiemstra H, Kuhry P, Melief B, van Geel B, van der Hammen T, van Reenen G, Wille M (2001) Mid-to LateHolocene pollen-based biome reconstructions for Colombia. Quat Sci Rev 20:1,289-1,308

Marchant R, Boom A, Hooghiemstra H (2002) Pollen-based biome reconstructions for the past 450, $000 \mathrm{yr}$ from the Funza-2 core, Colombia: comparisons with model-based vegetation reconstructions. Palaeogeogr Palaeoclimatol Palaeoecol 177:29-45

Markgraf V (1989) Palaeoclimates in Central and South America since 18000 BP based on pollen and lake-level records. Quat Sci Rev 8:1-24

Miehe G, Miehe S (1994) Zur oberen Waldgrenze in tropischen Gebirgen. Phytocoenologia 24:53-110

Niemann H, Behling H (2008a) Late Quaternary vegetation, climate and fire dynamics inferred from the El Tiro record in the southeastern Ecuadorian Andes. J Quat Sci 23:203-212

Niemann H, Behling H (2008b) Past vegetation and fire dynamics. In: Beck E, Bendix J, Kottke I, Makeschin F, Mosandl R (eds) Gradients in a tropical mountain ecosystem of Ecuador. Ecol Stud 198. Springer, Berlin, pp 101-111

Niemann H, Behling H (2010) Late Holocene environmental change and human impact inferred from three soil monoliths and the Laguna Zurita multi-proxi record in the southeastern Ecuadorian Andes. Veget Hist Archaeobot 19:1-15

Niemann H, Haberzettl T, Behling H (2009) Holocene climate variability and vegetation dynamics inferred from the (11, 700 cal yr BP) Laguna Rabadilla de Vaca sediment record in the south-eastern Ecuadorian Andes. Holocene 19:307-316

Richter M (2003) Using epiphytes and soil temperature for ecoclimatic interpretations in south Ecuador. Erdkunde 57:161-181

Richter M, Moreira-Muñoz A (2005) Climatic heterogeneity and plant diversity in southern Ecuador experienced by phytoindication. Rev Peru Biol 12:217-238
Richter M, Diertl KH, Peters T, Bussmann RW (2008) Vegetation structures and ecological features of the upper timberline ecotone. In: Beck E, Bendix J, Kottke I, Makeschin F, Mosandl $\mathrm{R}$ (eds) Gradients in a tropical mountain ecosystem of Ecuador. Ecol Stud 198. Springer, Berlin, pp 123-136

Sarmiento FO, Frolich LM (2002) Andean cloud forest treelines: naturalness, agriculture and the human dimension. Mt Res Dev 22:278-287

Troll C (1959) Die tropischen Gebirge. Ihre dreidimensionale klimatische und pflanzengeographische Zonierung. Ferd. Dümmlers, Bonn

Van 't Veer R, Islebe GA, Hooghiemstra H (2000) Climatic change during the Younger Dryas chron in northern South America: a test of the evidence. Quat Sci Rev 19:1821-1835

Van der Hammen T (1974) The Pleistocene changes of vegetation and climate in tropical South America. J Biogeogr 1:3-26

van der Hammen T, González E (1960) Holocene and Late Glacial climate and vegetation of Páramo de Palacio (Eastern Cordillera, Colombia, South America). Geol Mijnbouw 39:737-746

Van der Hammen T, Urrego CG (1978) Prehistoric man on the Sabana de Bogota: data for an ecological prehistory 25:179-190

Van Geel B, van der Hammen T (1973) Upper Quaternary vegetational and climatic sequence of the Fúquene area (Eastern Cordillera, Colombia). Palaeogeogr Palaeoclimatol Palaeoecol 14:9-92

Vélez MI, Metcalfe S, Hooghiemstra H, Mommersteeg H, Martínez I (2003) Pollen and diatom based environmental history since the Last Glacial Maximum from the Andean core Fúquene-7, Colombia. J Quat Sci 18:17-30

Walter H, Medina E (1969) Die Bodentemperatur als ausschlaggebender Faktor für die Gliederung der subalpinen und alpinen Stufe in den Anden Venezuelas. Ber Dtsch Bot Ges 82:275-281

Weng C, Bush MA, Chepstow-Lusty AJ (2004) Holocene changes of Andean alder (Alnus acuminata) in highland Ecuador and Peru. J Quat Sci 19:685-691

Weninger B, Jöris O, Danzeglocke U (2004) Calpal—the Cologne radiocarbon CALibration and PALaeoclimate research package. http://www.calpal.de. Accessed 22 Feb 2009

Wille M, Hooghiemstra H, Hofstede R, Fehse J, Sevink J (2002) Upper forest line reconstruction in a deforested area in northern Ecuador based on pollen and vegetation analysis. J Trop Ecol $18: 409-440$ 